\title{
Energetická náročnost budov a oceňování nemovitostí
}

\section{Energy Performance and Property Valuation}

Petr Holub*, Tomáš Trubačík

Šance pro budovy

\begin{abstract}
Abstrakt
Předložená práce se zabývá vztahem mezi energetickou náročností budovy a její cenou; byla prezentována $\mathrm{v}$ rámci konference ExFoS ve dnech 24.-25. 1. 2019. V práci jsou představeny zahraniční studie $\mathrm{v}$ této oblasti a jejich závěry je vysvětleno, jak může energetická třída nemovitosti indikovat její kvalitu. Závěrečná část se věnuje ekonomické stránce dané problematiky. Ukazuje pozitivní vztah mezi lepší energetickou tř́dou nemovitosti a nižšími účty za energie, což je něco, co může být do budoucna využito např́klad bankovním sektorem.
\end{abstract}

Klíčová slova: PENB, průkaz energetické náročnosti, energetická třída, cena nemovitosti.

\section{1. ÚVOD}

Budovy jsou odpovědné za přibližně 40 procent celkové spotřeby energie [13]. Největší podíl na spotřebě energie má vytápění a prŕíprava teplé vody. Účet za energie tedy vedle jednotkové ceny samotných energií a spotřebitelského chování významně závisí na energetické náročnosti dané budovy.

\begin{abstract}
The analysis presented during ExFoS conference on 24.-25. 1. 2019 examines the link between energy performance of buildings and the value of building. The analysis examines foreign studies in this field and explains why could the energy performance certificates indicate quality of the building. The last section shows the hidden economy of the energy performance. A ratio between better energy class and lower energy bills exists and may be further exploited for instance by the banking sector.
\end{abstract}

Keywords: EPC, Energy Performance Certificate, energy class, property value.

Důležitou součástí trhu s nemovitostmi, která umožňuje aktérům do jejich rozhodování zahrnout i otázky spojené s provozními náklady a umožňuje na tomto základě nemovitosti srovnávat, je průkaz energetické náročnosti budovy (PENB). Tento dokument, zpracovávaný autorizovaným energetickým specialistou podle metodiky uvedené ve vyhlášce č. 78/2013 Sb. o energetické náročnosti budov, prokazuje jednu z kvalit zboží na volném trhu

Tab. 1 Konečná spotřeba energie v domácnostech dle účelu užití [1, vlastní zpracování].

Tab. 1 Final energy consumption in households by type of end-use [1, custom processing].

\begin{tabular}{lc}
\hline \multicolumn{2}{c}{ Konečná spotřeba energie v domácnostech $(\mathbf{P J})$} \\
\hline Vytápění & $\mathbf{2 0 1 5}$ \\
Př́prava teplé vody & $\mathbf{1 9 7}$ \\
Vaření & 51 \\
Spotřebiče a osvětlení & 20 \\
Ostatní & 21 \\
Celkem & 5 \\
\hline
\end{tabular}

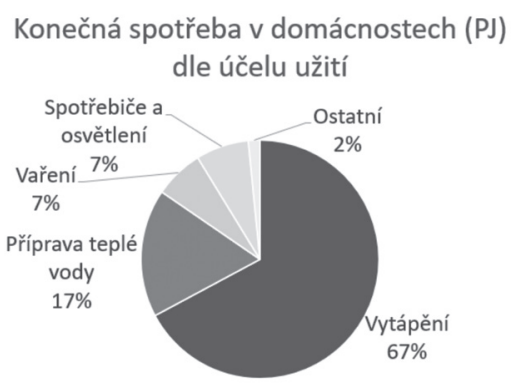




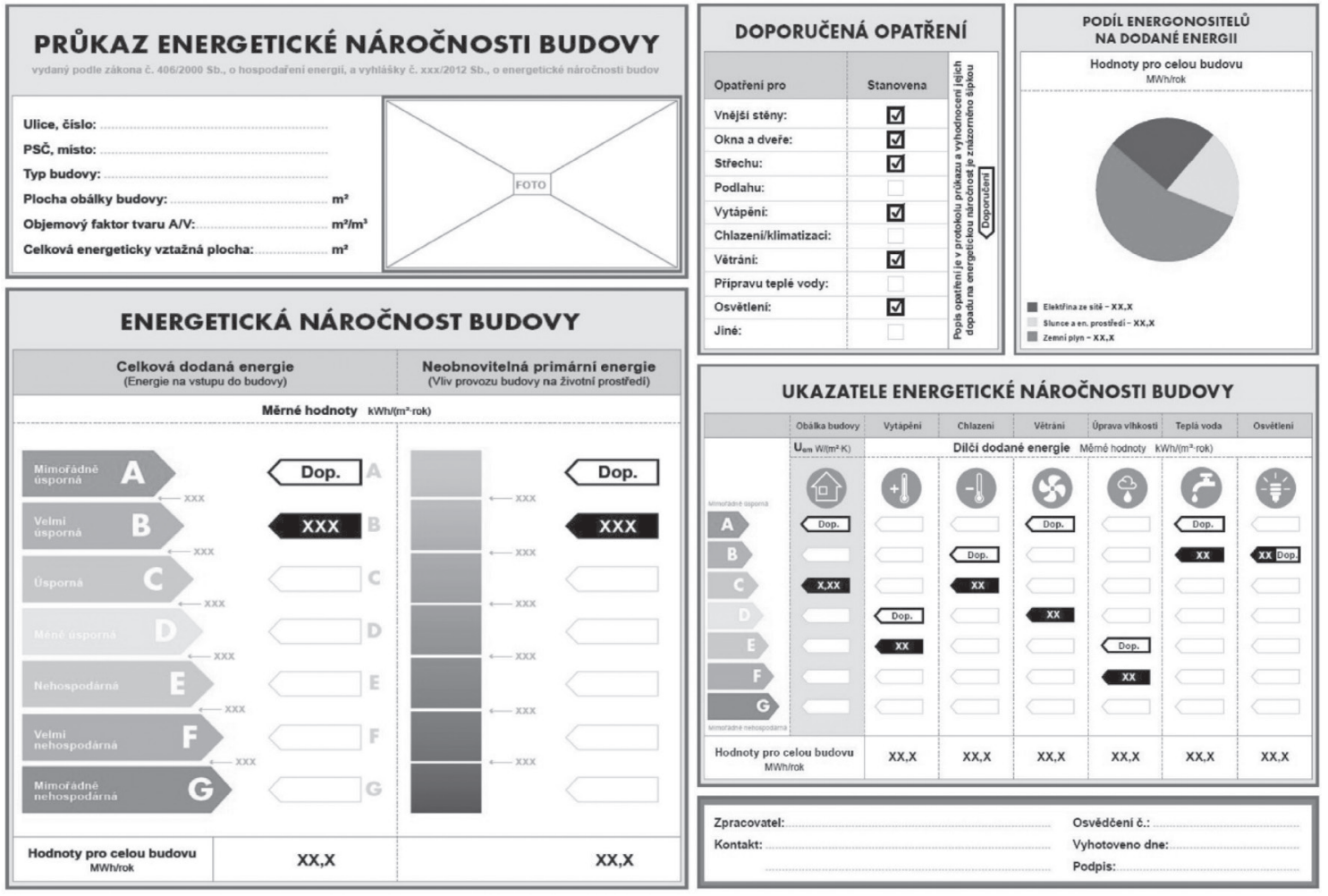

Obr. 1 Grafické znázorněni průkazu energetické náročnosti budov [11].

Fig. 1 Graphic design of Energy Performance Certificate [11].

a dává tak kupující straně informaci pro správné rozhodnutí. S energeticky úspornými nemovitostmi se pak pojí i řada dalších benefitů nad rámec ušetřených provozních nákladů, např. zdravější vnitřní prostředí nebo větší komfort uživání, což se pozitivně projevuje na jejich hodnotě z dlouhodobého hlediska.

\section{VZTAH ENERGETICKÉ NÁROČNOSTI A CENY NEMOVITOSTI}

\subsection{Energetická náročnost budov}

Hodnocení energetické náročnosti budov je na evropském trhu běžnou praxí od roku 2002, kdy byla schválena první evropská směrnice o energetické náročnosti budov (2002/91/ EC), která zavedla minimální požadavky pro novostavby i pro větší rekonstrukce a přišla s nutností certifikace budov dle jejich energetické náročnosti. Do české legislativy se povinnost promítla vyhláškou č. 148/2007 Sb. o energetické náročnosti budov, která představila mj. i grafickou podobu PENB. Novela směrnice z roku 2010 [13] vyjasnila požadavky na energetickou náročnost budovy, která ukazuje výpočtové množství energie, nutné pro pokrytí roční potřeby energie spojené s typickým užíváním budovy (zahrnuje energii používanou pro vytápění, chlazení, větrání, teplou vodu a osvětlení). Současná podoba PENB vychází z vyhlášky č. 78/2013 Sb., která nahradila vyhlášku č. 148/2007 Sb. a budovy rozděluje do sedmi tříd A až G (obr. 1).

\subsection{Studie mapující vztah ceny a energetického zatřídění}

Cenu nemovitosti ovlivňuje řada faktorů jako je její poloha, poptávka v daném místě, vzhled nemovitosti nebo její konstrukce resp. okamžitý technický stav. Ten často souvisí právě s energetickou náročností. A řada studií tuto souvislost naznačuje či potvrzuje.

Dle studie KPMG pro Immovalue z roku 2010 je energetická třída nemovitosti její určitou (,zelenou“) přidanou hodnotu, za kterou je kupující ochoten si připlatit - nejčastěji do $5 \%$ za tř́́du. Cena vyšší o více než $5 \%$ byla pak spojována pouze s velice úspornými nemovitostmi a jejich nálepkami jako „zelený“ či „,udržitelný“ projekt. Takové projekty vedle nízké energetické náročnosti obsahovaly i jiné aspekty udržitelnosti a hodnotily mj. celý životní cyklus budovy (a v ní použitých materiálů), kvalitu vnitřního prostředí atp. [2].

Studie Institutu pro evropskou environmentální politiku pro DG Energy (IEEP 2013) zkoumala vztah energetické třídy a ceny nemovitosti $\mathrm{z}$ hlediska prodeje i pronájmu na několika trzích v západní Evropě. Výsledky studie ukázaly, že s lepší energetickou tř́ídou nemovitosti rostla i její cena, a to jak prodejní, tak cena nájemného (viz obr. 2) [3].

Podobné výsledky, mapující pozitivní vztah energetické třídy nemovitosti a její ceny, přnáší i studie z katedry ekonomie Oxfordské univerzity, která mapovala nemovitosti v Irsku. Vliv energetické třídy se více projevoval u prodejů než u pronájmu a v místech či obdobích s horšími tržními podmínkami - například na venkově, kde je obecně menší poptávka, nebo v obdobích, kdy není tak výhodné či snadné si půjčit (autoři si to vysvětlovali tím, že v takovém období je také složitější zafinancovat případnou renovaci po koupi horší třídy nemovitosti) [4].

V České republice zatím výzkumů na podobné téma nebylo realizováno př́lišs. Přesto lze najít práce, které se vlivem PENB na cenu nemovitosti zabývají. Jmenujme např́klad diplomovou práci z VUT v Brně z roku 2014, kde autorka vyčíslila cenový 
Figure 17: Effect of one-letter or equivalent improvement in EPC rating across European property markets ( $95 \%$ confidence interval shown; see also notes in the text)

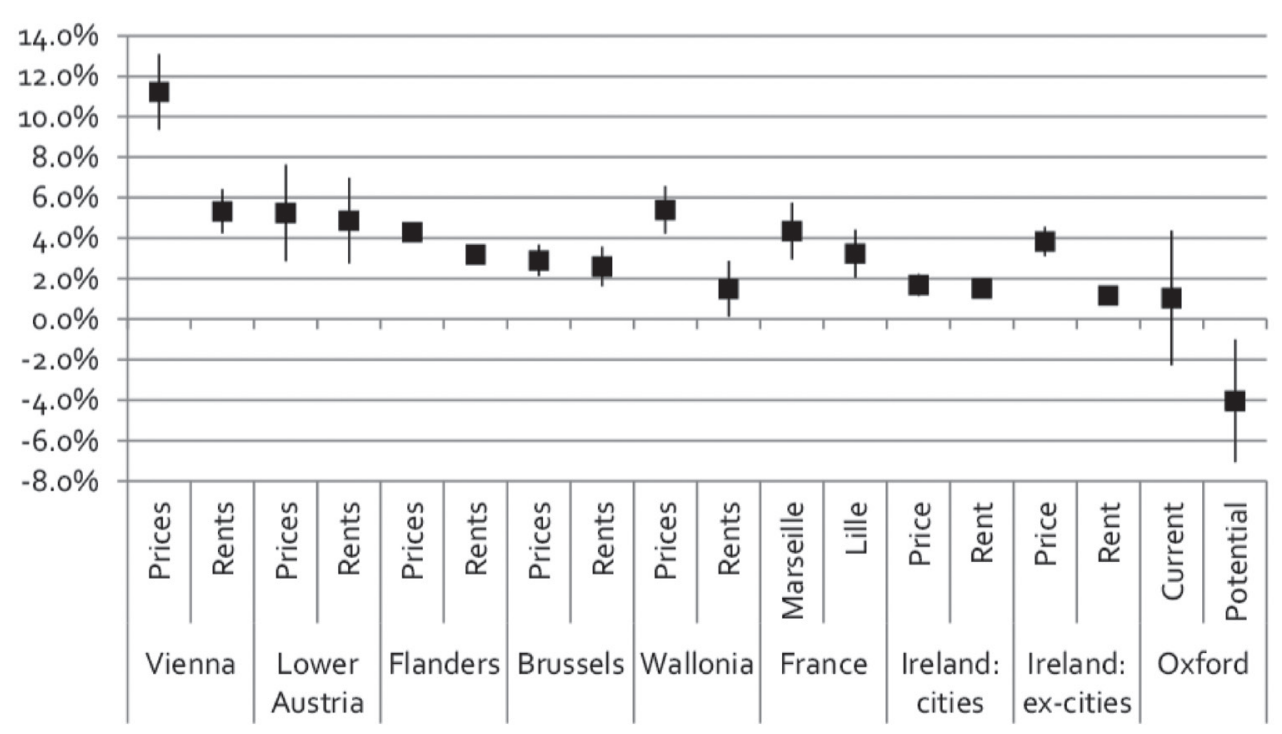

Obr. 2 Dopad na cenu způsobený rozdilem jedné energetické třidy [2].

Fig. 2 Impact on price due to a single energy class difference [2].

rozdíl mezi jednotlivými třídami nemovitostí v Královehradeckém kraji pro rodinné domy v průměru na 63000 Kč na jednu tř́du [5].

\section{BUSINESS CASE}

Jak bylo uvedeno výše, průkaz energetické náročnosti je stanoven na základě výpočtových hodnot a standardizovaného užívání budovy. Nicméně ve statistickém vzorku lze jednotlivým tř́dám přiřadit odhad ročních nákladů na energie.

Dle oborové aliance Šance pro budovy se průměrné roční náklady na vytápění a teplou vodu dle jednotlivých tříd liší v řádech tisíců korun, a to jak u rodinných domů, tak u bytových jednotek v rámci bytového domu.
Možná měsíční úspora nákladů plynoucí z rozdílu mezi třídami $\mathrm{C}$ a A je u průměrného bytu zhruba $500 \mathrm{Kč} \mathrm{a} \mathrm{u} \mathrm{průměrného}$ rodinného domu přes $1000 \mathrm{Kč}$. To je disponibilní př́ijem „navíc,“ který může být vlastníkem využit k pokrytí jiných výdajů - např́iklad ke splátce úvěru. $Z$ tohoto důvodu začíná být energetická náročnost nemovitostí zajímavá i pro bankovní sektor.

V červnu 2015 činila průměrná úroková sazba u nově sjednaných hypotečních úvěrů 2,05\% \% Průměrná výše hypotéky 1829483 Kč a splátka průměrné hypotéky s dobou splatnosti 20 let při nově uzavřené smlouvě byla 9298 Kč měsíčně. Průměrná úspora plynoucí z využití nejlepší třídy energetické náročnosti tak činí $\mathrm{k}$ průměrné splátce hypotéky cca $5 \% \mathrm{v}$ př́ípadě bytu a cca $12 \%$ v př́ípadě rodinného domu (KPMG 2015).

\section{Průměrné náklady na vytápění dle energetické třídy}

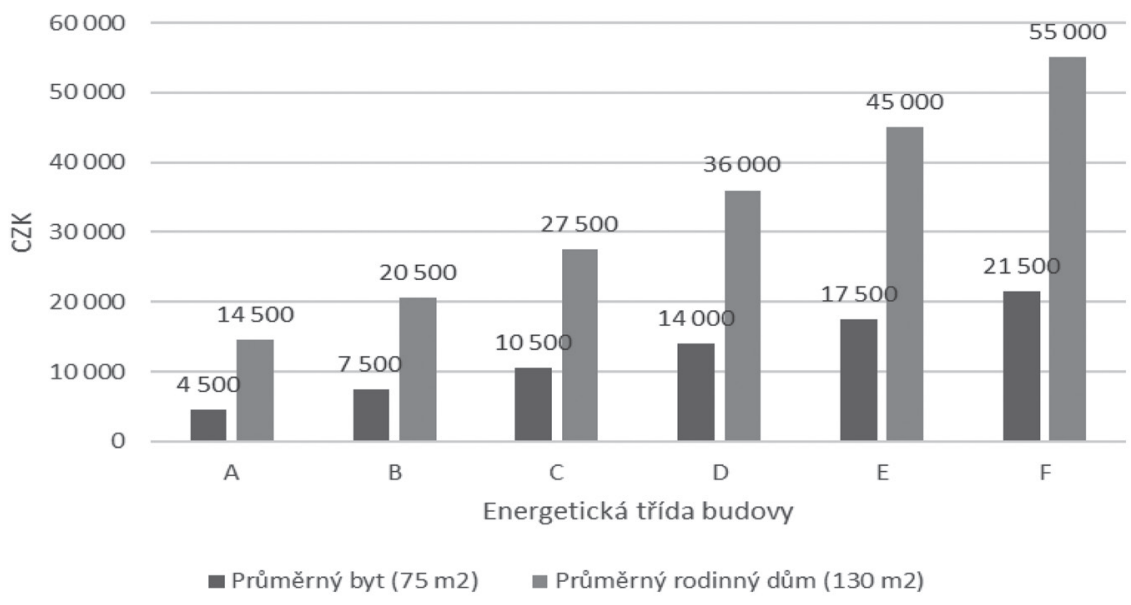

Obr. 3 Prưměrné roční náklady na vytápění dle energetické třídy budovy [6].

Fig. 3 Average annual heating costs per energy performance rating [6]. 


\begin{tabular}{ccc}
\hline Rating category & All & Defaulted \\
\hline A & 13.95 & 0.37 \\
B & 17.67 & 0.45 \\
C & 27.9 & 0.56 \\
D & 9.52 & 0.78 \\
E & 4.08 & 1.21 \\
F & 11.36 & 0.87 \\
G & 15.52 & 0.94 \\
\hline Total & 100 & 0.66 \\
\hline
\end{tabular}

Percentage of defaults increases with lower EE-rating

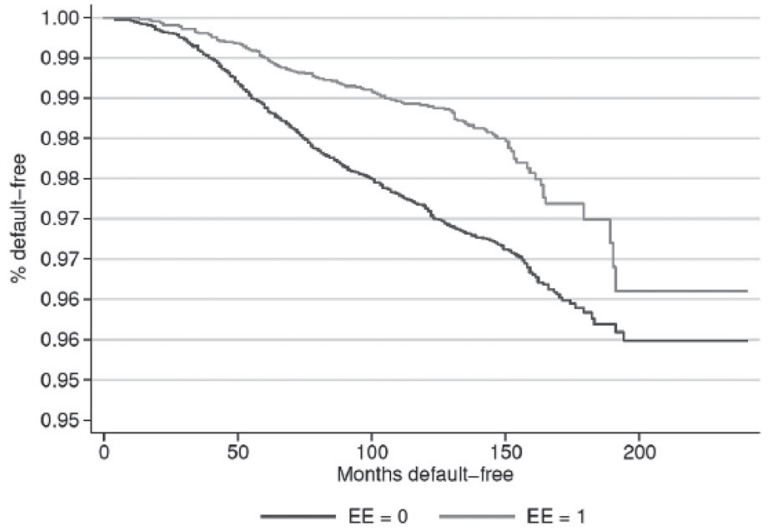

EE mortgages seem to survive for a longer time period

Obr. 4 Schopnost splácet a energetická třída nemovitosti [7].

Fig. 4 Default rate and energy performance rating [7].

Evropská iniciativa Energy Efficient Mortgages Initiative spolu se zapojenými bankami tento vztah zkoumá. Z jejich dat již nyní vyplývá, že hypotéky poskytované na lepší energetickou třídu nemovitostí poskytují větší jistotu splácení.

\subsection{Investiční vícenáklady novostaveb v pasivním standardu}

Pokud jde o novostavby, je otázkou, do jaké míry je výstavba domu v pasivním standardu spojena s vícenáklady oproti doporučovanému standardu. Pokud je k novostavbě přistupováno od prvního konceptu se záměrem vybudovat funkční stavbu v pasivním standardu nemusí se vícenáklady projevit. Uvažovanými proměnnými totiž jsou nejen energetická opatření, ale i vhodné umístění a orientace budovy, optimalizovaný tvar, optimalizovaná plocha a orientace zasklení z hlediska světových stran, kvalitní obálka budovy včetně oken a například vhodné dispoziční řešení (Čejka, Šafařík 2012).

Studie Centra pasivního domu (2014) z českého prostředí tyto závěry o neexistující korelaci mezi standardem pasivního domu a vyššími náklady potvrzuje. Pro minimalizaci zkreslení byly srovnávány náklady hrubé stavby u 49 objektů rodinných domů, realizovaných v letech 2009-2013 v pasivním standardu z hlediska programu Nová zelená úsporám. Jednotková cena za $\mathrm{m}^{3}$ obestavěné plochy se pohybovala v rozmezí $2.930 \mathrm{Kč} / \mathrm{m}^{3}$ až $8.043 \mathrm{Kč} / \mathrm{m}^{3}$.

$\mathrm{Na}$ obr. 5 představený graf ilustruje, že za průměrnou cenu $4500 \mathrm{Kč} / \mathrm{m}^{3}$ lze postavit dům s měrnou potřebou tepla $14 \mathrm{kWh} / \mathrm{m}^{2} /$ rok, ale i $38 \mathrm{kWh} / \mathrm{m}^{2} /$ rok. Podobně pak, že jednotková cena u domu se spotřebou $15 \mathrm{kWh} / \mathrm{m}^{2}$ může být $4000 \mathrm{Kč} / \mathrm{m}^{3}$, ale i $8000 \mathrm{Kč} / \mathrm{m}^{3}$.

Pokud i přesto uvažujeme vícenáklady pasivního standardu, budou pravděpodobně spojeny s použitím kvalitnějších oken, kvalitnější obálky, zajištění dostatečného větrání a kvalitnější projektovou přípravou, nicméně nepřesáhnou $10 \%$ oproti běžné výstavbě (Čejka, Šafařík 2012).

Lze tedy říct, že vícenáklady na výstavbu domu v pasivním standardu pravděpodobně nepřesáhnou rozdíl v prodejní ceně $(10 \%$ za dvě energetické třídy, z $\mathrm{C}$ do A).

\section{Cena vs. potřeba tepla na vytápění}

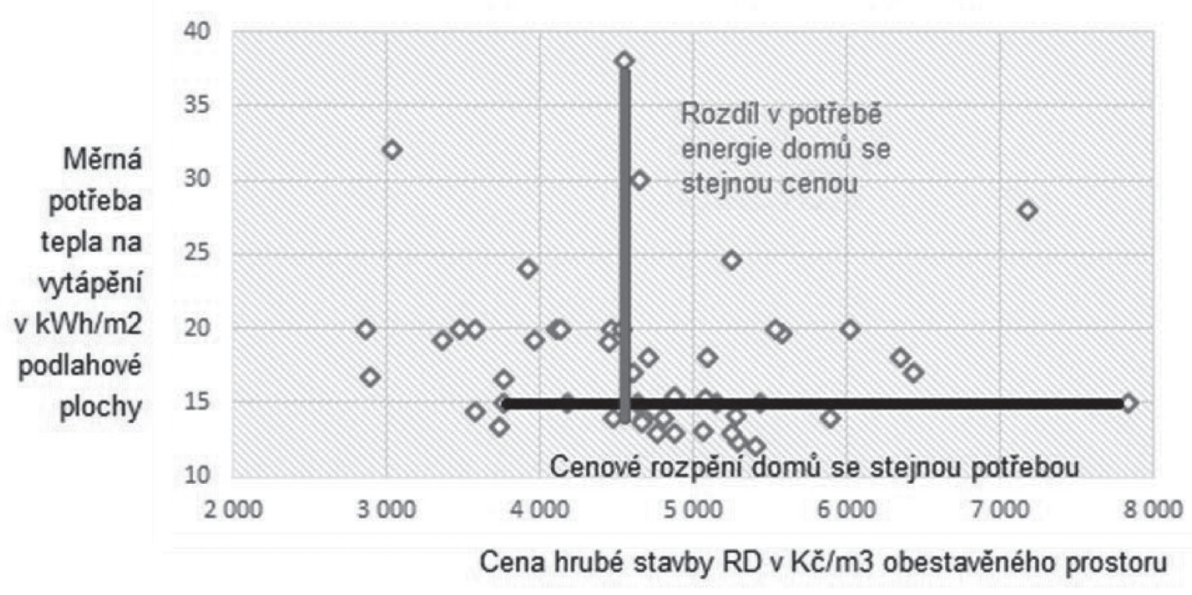

Obr. 5 Cena vs. potřeba tepla na vytápěni [9].

Fig. 5 Single family house costs vs. heating needs [9]. 


\subsection{Ekonomická návratnost investice do energeticky úsporné renovace}

Křivka celkových nákladů energeticky úsporné renovace (investiční plus diskontované provozní náklady) má ploché minimum v části mezi střední a důkladnou renovací (odvíjí se od tloušt'ky izolantu, kvality oken, zajištění větrání, účinnosti zdroje, ap.). Z Průzkumu fondu budov a Strategie renovace budov ${ }^{1)}$ plyne investiční náročnost na úsporu jednoho gigajoulu ve výši asi 8 až 10 tisíc Kč vč. DPH. V tom jsou zahrnuty i ostatní související náklady, nemající přímý vliv na energetickou náročnost (atiky, okapy, lešení apod.). Při průměrné ceně energie (zemní plyn, dálkové teplo, částečně elektrrina) kolem $500 \mathrm{Kč/GJ}$ je prostá návratnost této investice bez státní podpory kolem 20 let. Vnitřní výnosové procento pak je běžně v rozmezí 4 až $6 \%$ p.a.

\section{ZÁVĚR}

Průkazy energetické náročnosti budovy jsou již běžnou součástí trhu s nemovitostmi. Lepší zatřídění by mělo indikovat kvalitnější budovu a pro jejího (budoucího) majitele nižší náklady na provoz dané budovy. Data z výše uvedených výzkumů tuto skutečnost potvrzují, ale zároveň upozorňují, že záleží na situaci na trhu a že někdy je lepší energetická třída spíše vnímána pouze jako součástí jiných vlastností budovy či projektu jako je např́klad „udržitelnost“, po kterých je poptávka. S ohledem na jasnou ekonomickou návratnost lepšího energetického zatřídění budovy může do budoucna hrát PENB větší roli s tím, jak tuto skutečnost bude reflektovat bankovní sektor.

\section{LITERATURA}

[1] CZSO: Spotreba paliv a energií v domácnostech, ENERGO 2015, Český statistický úrad. <https://www.czso.cz/ documents/10180/50619982/ENERGO_2015.pdf/86331734a917-438a-b3c2-43a5414083fc?version=1.4>

\footnotetext{
1) Šance pro budovy 2014, součást Národního akčního plánu pro energetickou účinnost - MPO 2014, https://www.mpo.cz/assets/ dokumenty/50711/63238/651839/priloha003.pdf
}

[2] KPMG: Integration of Energy Performance and Life-Cycle Costing into Property Valuation Practice, Immovalue 2010. $<$ https://ec.europa.eu/energy/intelligent/projects/sites/ieeprojects/files/projects/documents/immovalue_final_publishable report_en.pdfs

[3] IEEP: Energy performance certificates in buildings and their impact on transaction prices and rents in selected EU countries. DG ENERGY 2013. https://ec.europa.eu/energy/sites/ener/files/ documents/20130619-energy_performance_certificates_in_ buildings.pdf

[4] LYONS, R., C., HYLAND, M., LYONSO, S. The value of domestic building energy efficiency - evidence from Ireland, Department of Economics, University of Oxford, 2012. <https:// www.economics.ox.ac.uk/department-of-economics-discussionpaper-series/the-value-of-domestic-building-energy-efficiencyevidence-from-ireland $>$

[5] NOVÁKOVÁ, T. Vliv PENB na cenu nemovitosti v Královéhradeckém kraji, ÚSI VÚT, 2014 Brno. <https:// www.vutbr.cz/www_base/zav_prace_soubor_verejne.php?file_ $\mathrm{id}=86458>$

[6] ŠANCE PRO BUDOVY. Návrh metodiky hodnocení rizik pri poskytováni produktů na bankovním retailovém trhu podle energetické náročnosti financované nemovitosti, 2015.

[7] EEMI: Energy efficient Mortgages Action Plan (EeMAP) \& Energy efficiency Data Protocol and Portal (EeDaPP), EEMI 2018. < https://ec.europa.eu/info/sites/info/files/012_ps1_andrea bedin_seif_frankfurt_05-12-18.pdf>

[8] ČEJKA, M., ŠAFAŘÍK, M. Ekonomické porovnáni provozu pasivního domu a běžné výstavby. TZB-info.cz 2012. <http:// stavba.tzb-info.cz/pasivni-domy/8238-ekonomicke-porovnaniprovozu-pasivniho-domu-a-bezne-vystavby>

[9] CENTRUM PASIVNÍHO DOMU. 2014. Dostupné z: <http:// www.pasivnidomy.cz/unikatni-studie-ukazala-ze-pasivni-domynemusi-byt-drahe/t4126>

[10] KPMG. Role energetické náročnosti budov v hodnocení rizik při poskytováni produktio na bankovním retailovém trhu. Česká bankovní asociace. 2015.

[11] Vyhláška č. 78/2013 Sb. o energetické náročnosti budov

[12] EC EUROPA. Energy performance of buildings, 2018. Dostupné z: https://ec.europa.eu/energy/en/topics/energy-efficiency/energyperformance-of-buildings

[13] Directive 2010/31/EU of the European Parliament and of the Council of 19 May 2010 on the energy performance of buildings

[14] HOLUB, P., TRUBAČÍK, P. Energetická náročnost budov a oceňování nemovitostí In Sbornik príspěvků konference Expert Forensic Science Brno 2019. VUT v Brně, 2019., s. 314-319. ISBN 978-80-214-5708-9.

\section{Správná citace:}

PETR HOLUB, P., TRUBAČÍK, T. Energetická náročnost budov a oceňování nemovitostí. Soudní inženýrství, 2019 , 30(3), 37-41. DOI: http://dx.doi.org./10.13164/SI.2019.3.37. ISSN 1211-443X. 